\title{
Wastewater Monitoring of SARS-CoV-2 from Acute Care Hospitals Identifies Nosocomial
}

4 Nicole Acosta ${ }^{1}$, María A. Bautista ${ }^{2}$, Jordan Hollman ${ }^{3,4}$, Janine McCalder $^{1,2}$, Alexander Buchner

5 Beaudet $^{2}$, Lawrence Man ${ }^{2}$, Barbara J. Waddell ${ }^{1}$, Jianwei Chen ${ }^{2}$, Carmen $\mathrm{Li}^{2}$, Darina Kuzma ${ }^{5}$,

6 Srijak Bhatnagar ${ }^{2}$, Jenine Leal ${ }^{1,6,7,10}$, Jon Meddings ${ }^{8}$, Jia $\mathrm{Hu}^{7,9,10}$, Jason L. Cabaj ${ }^{7-10}$, Norma J.

7 Ruecker ${ }^{11}$, Christopher Naugler ${ }^{7,12}$, Dylan R. Pillai ${ }^{1,12-14}$, Gopal Achari ${ }^{4}$, M. Cathryn Ryan ${ }^{3}$, John

8 M. Conly ${ }^{1,6,8,10,12,13}$, Kevin Frankowski ${ }^{5}$, Casey RJ Hubert ${ }^{2}$ and Michael D. Parkins ${ }^{1,8,13}$

$10{ }^{1}$ Department of Microbiology, Immunology and Infectious Diseases, University of Calgary,

11 Calgary, Canada

$12{ }^{2}$ Department of Biological Sciences, University of Calgary, Calgary, Canada

$13{ }^{3}$ Department of Geosciences, University of Calgary, Calgary, Canada

$14{ }^{4}$ Department of Civil Engineering, University of Calgary, Calgary, Canada

$15{ }^{5}$ Advancing Canadian Wastewater Assets, University of Calgary, Calgary, Canada

$16{ }^{6}$ Infection Prevention and Control, Alberta Health Services, Calgary, Canada

$17{ }^{7}$ Department of Community Health Sciences, University of Calgary, Calgary, Canada

$18{ }^{8}$ Department of Medicine, Cumming School of Medicine, University of Calgary, Calgary,

19 Canada 
medRxiv preprint doi: https://doi.org/10.1101/2021.02.20.21251520; this version posted February 23, 2021. The copyright holder for this preprint

(which was not certified by peer review) is the author/funder, who has granted medRxiv a license to display the preprint in perpetuity.

All rights reserved. No reuse allowed without permission.

20

21

22

23

24

25

26

27

28

29

30

31

32

33

34

35

36

37
${ }^{9}$ Provincial Population \& Public Health, Alberta Health Services, Calgary, Canada

${ }^{10}$ O'Brien Institute for Public Health, University of Calgary, Calgary, Canada

${ }^{11}$ Water Quality Services, City of Calgary, Calgary, Canada

12 Department of Pathology and Laboratory Medicine, University of Calgary, Calgary, Canada

${ }^{13}$ Snyder Institute for Chronic Diseases, University of Calgary, Calgary, Canada

${ }^{14}$ Alberta Precision Laboratories, Alberta Health Services, Calgary, Canada

Key words: COVID-19, sewage, wastewater, wastewater-based epidemiology, hospital-acquired

Running Title: SARS-CoV-2 in Hospital Wastewaters

Abstract word count: 246

Manuscript word count: 2998

Figures: 2

Tables: 3

Supplemental Material included

\section{Key-points summary:}

SAS-CoV-2 RNA is detectable in hospital wastewater. Wastewater SARS-CoV-2 RNA increases in conjunction with COVID-19-related hospitalizations. Spikes in SARS-CoV-2 wastewater signal correspond to incident hospital-acquired cases and outbreaks, suggesting passive surveillance via wastewater has great promise for COVID-19 monitoring. 
medRxiv preprint doi: https://doi.org/10.1101/2021.02.20.21251520; this version posted February 23, 2021. The copyright holder for this preprint (which was not certified by peer review) is the author/funder, who has granted medRxiv a license to display the preprint in perpetuity. All rights reserved. No reuse allowed without permission.

$39 *$ Corresponding author:

40 Michael D. Parkins, Associate Professor, University of Calgary.

41 Postal address: 3330 Hospital Drive, NW, Calgary, Alberta, T2N 4N1. CANADA.

42 e-mail: mdparkin@ucalgary.ca

43 Phone: 403-220-5951, Fax: 403-270-2772.

44

45 Alternative corresponding author:

46 Casey RJ Hubert, Associate Professor, University of Calgary

47 Postal address: 2500 University Gate NW, Calgary, AB T2N 1N4. CANADA

48 e-mail: chubert@ucalgary.ca

49 Phone: 403-220-7794, Fax 403-289-9311

50

51 
ABSTRACT

53 Background: SARS-CoV-2 has been detected in wastewater and its abundance correlated with community COVID-19 cases, hospitalizations and deaths. We sought to use wastewater-based detection of SARS-CoV-2 to assess the epidemiology of SARS-CoV-2 in hospitals.

Methods: Between August and December 2020, twice-weekly wastewater samples from three tertiary-care hospitals (totaling $>2100$ dedicated inpatient beds) were collected. Wastewater samples were concentrated and cleaned using the 4S-silica column method and assessed for SARSCoV-2 gene-targets (N1, N2 and E) and controls using RT-qPCR. Wastewater SARS-CoV-2 as measured by quantification cycle $(\mathrm{Cq})$, genome copies and genomes normalized to the fecal

61 biomarker PMMoV were compared to the total daily number of patients hospitalized with active COVID-19, confirmed cases of hospital-acquired infection, and the occurrence of unit-specific outbreaks.

Results: Of 165 wastewater samples collected, 159 (96\%) were assayable. The N1-gene from SARS-CoV-2 was detected in $64.1 \%$ of samples, N2 in $49.7 \%$ and $\mathrm{E}$ in $10 \%$. N1 and N2 in wastewater increased over time both in terms of amount of detectable virus and the proportion of samples that were positive, consistent with increasing hospitalizations (Pearson's r=0.679, $\mathrm{P}<0.0001$, Pearson's $\mathrm{r}=0.728, \mathrm{P}<0.0001$, respectively). Despite increasing hospitalizations through

71 SARS-CoV-2 N1-RNA (median 112 copies/ml) versus outbreak-free periods (0 copies/ml; $\mathrm{P}<0.0001)$. 
medRxiv preprint doi: https://doi.org/10.1101/2021.02.20.21251520; this version posted February 23, 2021. The copyright holder for this preprint

(which was not certified by peer review) is the author/funder, who has granted medRxiv a license to display the preprint in perpetuity.

All rights reserved. No reuse allowed without permission.

73 Conclusions: Wastewater-based monitoring of SARS-CoV-2 represents a promising tool for

74 SARS-CoV-2 passive surveillance and case identification, containment, and mitigation in acute-

75 care medical facilities.

76 


\section{INTRODUCTION}

SARS-CoV-2 RNA is present in the feces of infected individuals - appearing just prior or concomitant with symptoms[1]. Accordingly, leaders in the field of wastewater-based epidemiology leveraged their expertise to study this emerging infectious disease[2,3]. Medema $e t$ al first reported SARS-CoV-2-RNA in Dutch wastewater-treatment plants (WW-TP)[4]. Several groups have since adapted this technology to understand community disease-burden[5-8]. Recent studies suggest that SARS-CoV-2-RNA increases in WW-TP precede clinically diagnosed cases by $0-2$ days and associated hospitalizations by $1-4$ days[6].

Between 4-8\% of individuals with COVID-19 will be hospitalized, with age and co-morbidities being key risk factors[9-11]. Nosocomial-transmission and outbreaks affecting patients and health care workers $(\mathrm{HCW})$ are not uncommon, although drivers remain to be fully understood $[12,13]$. While hospital-acquisition is rare (0.8-5 cases/10,000 patient-days in communities with high disease burden), public fear of acquiring COVID-19 from hospitals has resulted in reduced healthresource utilization and hospital avoidance, often to the detriment of patients[14, 15]. Accordingly, hospital-based detection tools are needed to understand the epidemiology of COVID-19 and potentially mitigate spread.

Hospitals hold great promise in understanding SARS-CoV-2 wastewater-generated data. Owing to their proximity to affected individuals in the municipal sewershed relative to WW-TP (i.e., shorter transit time for signal degradation[1]), hospitals may aid in understanding SARS-CoV-2 wastewater dynamics. Compared to the general community, hospitals are much more likely to comprehensively monitor and identify all cases within their populations. Furthermore, outbreaks in hospitals are rapidly and comprehensively investigated. For these reasons we embarked on this 
medRxiv preprint doi: https://doi.org/10.1101/2021.02.20.21251520; this version posted February 23, 2021. The copyright holder for this preprint (which was not certified by peer review) is the author/funder, who has granted medRxiv a license to display the preprint in perpetuity.

All rights reserved. No reuse allowed without permission.

99

100

101

102

103

104

105

106

107

108

109

110

111

112

113

114

115

116

117

118

119

120

study to determine relationships between hospital SARS-CoV-2 wastewater dynamics and COVID-19 hospitalizations, nosocomial-transmissions and outbreaks.

\section{METHODS}

\section{Acute-care hospitals and hospital information systems}

We monitored SARS-CoV-2-RNA in the wastewater from three of Calgary's four adult tertiarycare hospitals, accounting for $89 \%$ of staffed-inpatient beds (Supplementary Material). Daily prevalent-hospitalized cases were defined as those with laboratory-confirmed COVID-19 within 14 days, remaining on contact/droplet precautions. Hospital-acquired cases were defined as patients who were admitted to hospital $\geq 7$ days before COVID-19 symptom onset that were then confirmed by a positive RT-qPCR SARS-CoV-2 test; or a patient admitted to hospital for $\leq 7$ days confirmed to have hospital-acquired COVID-19 infection based on an epidemiological link. Hospital-acquired cases were separately recorded including the unit where they were acquired and are reported as hospital-wide signals for Hospital-1 and 2. Data for Hospital-3 are presented as 3A, 3B, 3C based on wastewater drainage outflows of different units. COVID-19 outbreaks were defined as any unit with $\geq 1$ confirmed hospital-acquired case(s) and/or $\geq 2$ confirmed COVID-19 cases in HCWs linked to a unit. This research was approved by the University of Calgary's Conjoint Health Regional Ethics Board (REB-20-1252).

\section{Wastewater sampling}

Wastewater samples were collected from August $5^{\text {th }}$ to December $17^{\text {th }}, 2020$ at three hospitals. Hospital-wide access through a single sampling point was not possible at Hospital-3 where an initial sampling point (Hospital-3A) captured the units predicted to be most relevant for COVID19 (including ICUs and dedicated COVID-19 care-units). Beginning October $1^{\text {st }}$ two additional 
121 sites were added, Hospital-3B and Hospital-3C, expanding coverage to all inpatient-care buildings.

122 Composite 24-hour samples of wastewater were collected using ISCO-GLS autosamplers

123 (Lincoln, Nebraska) placed inside sewer access points outside of hospitals. Samples were taken

124 from each location twice-weekly.

125 Sample Processing and RNA Purification

126 Sample preparation and molecular analysis were performed at separate sites to prevent cross

127 contamination. At ACWA, wastewater samples were processed with a $40 \mathrm{ml}$ aliquot taken to

128 comprise the sample. Each sample was spiked with a positive control - Bovilis ${ }^{\circledR}$ attenuated-

129 Coronavirus Vaccine (BCoV; Merck, \#151921). Sample processing and RNA purification was

130 conducted using the 4S-silica column method (i.e., Sewage, Salt, Silica and SARS-CoV-2) with

131 modifications[16]. Purified nucleic acids were transported on dry ice to the Health Sciences Centre

132 for molecular analysis. An extraction blank control was included for every processed sample batch

133 to ensure no contamination occurred.

\section{RT-qPCR analysis}

135 We used RT-qPCR to quantify SARS-CoV-2-RNA and controls in wastewater. Specific primers and probes (Supplementary Table-S1) were used to amplify two regions of the nucleocapsid gene

137 (i.e., N1 and N2) and a region of the envelope gene (i.e., E). Samples were considered positive for the presence of SARS-CoV-2 RNA-target if amplification passed a detection cycle threshold in

$139<40$ cycles for at least one of N1, N2 and/or E $[4,17,18]$. The quantification cycle (Cq) value was 140 used for calculations when this threshold was $<40$ cycles or reached between 40 and 45 cycles for 141 one target as long as another target reached the threshold in $<40$ cycles. Amplification of the 142 Pepper mild mottle virus (PMMoV) was employed to incorporate a human fecal biomarker control 
143 in order to normalize SARS-CoV-2 for the relative bioburden in samples[5]. RT-qPCR was

144 performed using a QuantStudio-5 Real-Time PCR System (Applied Biosystems) with each run

145 including no-template controls (NTCs) in triplicate. For N1, N2 and E-assays three positive

146 controls were included in each run. Samples where minimal signal for BCoV or PMMoV controls

147 were recovered were excluded from the analysis to mitigate false-negative results. Amplified

148 products from wastewater were also Sanger sequenced to confirm amplicons were derived from

149 SARS-CoV-2.

150 Statistical analysis

151 To compare the surrogate BCoV and PMMoV signals between hospitals, pairwise Mann-Whitney

152 tests were performed. Non-parametric Kruskal-Wallis tests were performed for multiple

153 comparisons of assay sensitivity and surrogate organism signals between sampling locations.

154 Pearson's correlation analyses were performed to determine the correlation of wastewater RNA-

155 signal measured as i). Cq, or ii). genome copies/ml of wastewater or iii). genome copies/genome

156 of PMMoV, vs daily-hospitalized cases. To assess for correlation of wastewater RNA-signal with

157 incident hospital-acquired cases, and to compensate for gaps owing to the twice-weekly sampling,

158 incident cases occurring +/- 3 days were compared to wastewater signals. To compare the SARS-

159 CoV-2 wastewater N1-signal observed during and between unit-outbreaks, each sample was

160 dichotomized as being collected within 3-days of a declared outbreak or not. Samples after a

161 declared outbreak were excluded until 3-days after the last in-hospital linked case was identified.

162 Statistical tests analyzed Hospital-1 and Hospital-2 together (given their capture of the entire

163 hospital-facility) and separately. Statistical analyses were conducted with GraphPad's Prism-8

164 software (La Jolla, CA). 


\section{RESULTS}

166

167

168

169

170

171

172

173

174

175

176

177

178

179

180

181

182

183

184

185

186

\section{Hospital SARS-CoV-2 Wastewater-RNA Kinetics}

In total, 165 hospital wastewater samples were collected and 159 assessed through 135-days of biweekly observation (40 Hospital-1; 39 Hospital-2; 34 Hospital-3A; 23 Hospital-3B; 23 Hospital3C). Six samples were excluded (Supplementary Figures S1-S2) SARS-CoV-2-RNA in wastewater increased over time in both the amount detectable and the proportion of samples that were positive, consistent with increasing cases and hospitalizations (Table 1, Supplementary Figure S3), coinciding with Calgary's COVID-19 'second wave'. We observed that the N1-assay had the best sensitivity for detecting SARS-CoV-2. Of the 96 samples tested using N1, N2 and Eassays (i.e., those received between August $1^{\text {st }}$ and October $29^{\text {th }}$ ), 9 samples were positive for all three targets, 28 were positive only for $\mathrm{N} 1$ and N2, and 39 were positive only for N1. After October $29^{\text {th }}$ the E-assay was dropped, and 69 samples were analyzed, 51 were positive for both N1 and N2 and 63 were positive just with N1. N1 and N2-signals measured as Cq were positively correlated (Pearson's r=0.710 Hospital-1, 0.762 Hospital-2, 0.792 Hospital-3A, 0.417 Hospital3B and 0.491 Hospital-3C) across all sites (Table 2). No-template and blank controls for sample processing and RNA purification were negative for all assays (i.e., N1, N2, E, BCoV and PMMoV). Standard curves for all RT-qPCR assays were within an acceptable range for efficiencies (75 to $162 \%$ ) and $\mathrm{R}^{2}$ (0.7 to 1.0$)$ (Supplementary Table-S2).

Hospital-1 had a higher proportion of SARS-COV-2-positive wastewater compared to Hospital-2 and Hospital-3, consistent with the higher burden of disease in NE Calgary (Table 1 and Figure 1). Following a large outbreak in Hospital-3 involving 45 patients, $43 \mathrm{HCW}$ and 5 visitors (beginning in a ward not monitored via Hospital-3A site and compounded by affected patients 
being transferred into different units through the hospital) that was declared on September $17^{\text {th }}$, wastewater sampling was expanded to include additional sites; Hospital-3B and Hospital-3C (Figure 2) to enable complete capture of Hospital-3.

\section{Wastewater SARS-CoV-2 signal correlates with total hospitalized COVID-19 cases}

We assessed the correlation between the SARS-CoV-2 wastewater-N1 with active-COVID-19 patients on contact/droplet isolation at each hospital. When assessed together, Hospital-1 and Hospital-2, we observed that as prevalent cases increased, the wastewater-signal measured as N1$\mathrm{Cq}$ also increased (Pearson's $\mathrm{r}=0.679, \mathrm{CI}: 0.529-0.787, \mathrm{P}<0.0001$ ). This was also true when Hospital-1 and Hospital-2 were assessed separately (Table 2). The same was observed when

SARS-CoV-2-N1 wastewater was normalized against copies of the PMMoV at Hospital-2, but only trended towards significance at Hospital-1 (Table 2). These same correlations are not as reliable at the Hospital-3 as we did not have access to prevalent cases as a function of sampling site. However, we continued to observe a positive correlation (Table 2) between prevalent cases vs N1-wastewater signal was measured as Cq at Hospital-3A (including dedicated COVID-19 care units and ICUs) (Pearson's r=0.717) or measured as copies/ml and copies normalized to PMMoV at Hospital-3C (Pearson's r=0.503 and 0.479, respectively).

\section{Wastewater SARS-COV2 signal correlates with hospital-acquired infections and outbreaks}

We observed a positive correlation between wastewater N1-signal and hospital-acquired cases at Hospital-1 and Hospital-2 when analyzed together (Pearson's r=0.389, CI: 0.177-0.566, P<0.001) and individually (Table 2). Hospital-3 data could not be fully analyzed as we did not have complete access to patient/HCW movements. Total SARS-CoV-2 as measured by $\mathrm{Cq}$ correlated with incident hospital-acquired cases at Hospital-3A when normalized relative to PMMoV. With 
respect to whether peaks in SARS-CoV-2 in wastewater associated with outbreaks, we compared SARS-CoV-2 signal from wastewater samples collected within 3 days of an outbreak being declared with samples collected during outbreak-free periods. When Hospital-1 and Hospital-2 were analysed together, we observed significant differences in median SARS-CoV-2 N-1 between outbreak-free periods vs outbreak periods when measured as copies/ml (0 [IQR: 0-57] vs 112 [IQR: 12-1726], P<0.0001) and normalized for PMMoV (0 [IQR: 0-0.06] vs 0.17 [IQR: 0.060.89], $\mathrm{P}=0.0003$ ). We observed that at each of Hospital-1, Hospital-2 and Hospital-3A there were significant differences in median SARS-CoV-2-N1 measured using copies/ml between outbreak and outbreak-free periods (Table 3). Similarly, the same trend was observed at Hospital-1 and Hospital-3A when wastewater SARS-CoV-2-N1 was normalized for PMMoV (Table 3).

\section{DISCUSSION}

Hospital-associated outbreaks of COVID-19 are increasingly being reported. Early data suggests that patients with nosocomial COVID-19 may fare worse than those with community-acquired disease, experiencing longer hospital stays but not increased mortality[13]. This observation balances the opposing impacts of increased co-morbidities and medical acuity in hospitalizedindividuals on one-hand, with the potential for earlier detection and more rapid supportive care/treatment on the other.

Preventing nosocomial transmission of COVID-19 is challenging for a myriad of reasons[19]. In addition to its highly infectious nature, accurate identification, triage, and effective isolation of cases is exceedingly difficult. While COVID-19 has a typical incubation period of 5-7 days, it can take as long as 14 days to manifest such that identifying evolving symptoms in previously admitted patients is challenging[20,21]. Furthermore, up to $40 \%$ of individuals (including patients and 
231 HCW) may be asymptomatic, pauci-symptomatic, or pre-symptomatic- each just as likely to

232 transmit infection as symptomatic individuals[22-24]. Despite rigorous infection control protocols,

233 nosocomial infections continue to occur. Novel strategies to understand the epidemiology of

234 SARS-CoV-2 in hospitals are therefore urgently required. One such strategy may be the

235 monitoring of hospital wastewater[25].

236 To date, most wastewater-based SARS-CoV-2 RNA surveillance has focused on monitoring

237 community burden of disease by sampling WW-TP[5-8]. More recently, moving sampling

238 'upstream' in the wastewater-network, closer to patients, is actively being explored. The most

239 granular data comes from single-facility assessments. Passive wastewater surveillance could hold

240 promise as an early warning strategy, adaptable to both low- and high-risk facilities. Importantly,

241 if an incipient signal is detected in facility-wide wastewater samples, in-building plumbing systems

242 can be strategically sampled in a nested manner in order to confirm an outbreak location.

243 Here we demonstrate that both the frequency of positive samples and the abundance of SARS-

244 CoV-2 RNA in hospital wastewater systems correlated with increasing hospitalised cases -

245 analogous to WW-TP levels correlating with the COVID-19 community-diagnosed cases[5-8].

246 This was most evident using raw SARS-CoV-2 Cq values but was also evident when normalized

247 against PMMoV levels. We observed the N1-region of the nucleocapsid gene to be more sensitive

248 than $\mathrm{N}-2$, and E so low as to be dropped from our protocol. Other groups have reported similar

249 trends in that the N1-target is the most sensitive marker in WW-TP studies[4] and cruise ships[26].

250 Despite nosocomial cases and outbreaks representing a small fraction of the overall population of

251 patients hospitalized with COVID-19, these events were discernable by wastewater testing. The

252 natural history of SARS-CoV-2-RNA presence in the gastrointestinal tract remains incompletely 

may have great merit.

A key limitation to the identification of SARS-CoV-2 in wastewater samples, relative to clinical samples (e.g., swabs) is the massive volume of water in which samples are diluted. This necessitates sample concentration. While procedures for the efficient recovery of non-enveloped viruses exist, researchers continue to search for satisfactory protocols for enveloped viruses such as SARS-CoV-2[27]. Many groups have explored ways to improve the sensitivity of wastewater SARS-CoV-2 detection. Diagnostic platforms with improved sensitivity and more impervious to impurities in the wastewater matrix (i.e., digital droplet RT-PCR) also show considerable

271 promise $[28,29]$. Sampling in the proximal sewershed may lead to day-to-day variance resulting

272 in signal noise. This is particularly true for single-facility studies where potential extremes in

273 individual virus shedding could confound results; limited data suggests significant variations in 274 fecal viral load occur (from $10^{3.4}$ to $10^{7.6}$ )[30]. This is a key challenge that remains to be solved if 275 wastewater data is to be used in a meaningful way. Similarly, issues arise with attempts to 
normalize SARS-CoV-2 based on the contributing population. We chose to use the PMMoV as a fecal biomarker to control for variations in fecal loading - a particular risk when sampling takes place 'upstream' in the sewershed. While this marker has been validated in WW-TP samples where large and diverse populations contribute to sewage[31], hospitals are a much smaller collection of individuals and variations in PMMoV excretion owing to differences in diet could have a much larger impact[32].

By capturing longitudinal data from three tertiary-care hospitals ( $>2100$ inpatient beds) we have demonstrated that passive wastewater monitoring is indeed possible at a range of hospitalfacilities. Whereas Hospital-1 and Hospital-2 had a single municipal access point enabling surveillance of the entire facility - Hospital-3 required three locations to capture fully. As patients were frequently moved from one unit/building to another, either based on attending services geographic location, COVID-positive patient cohorting or need for ICU support, attributing SARS-CoV-2 signal in the wastewater of this facility was more complicated but nonetheless correlations were evident. Furthermore, while nursing staff is often assigned to individual units, many allied health workers and physicians work or consult throughout the entire facility. If passive wastewater monitoring is to be adapted for other aspects of nosocomial surveillance (i.e., antibiotic consumption, emergence of antimicrobial resistant organisms, etc.) - a keen insight into the collection network is required.

There are limitations of our work that merit discussion. Given the complexity involved in sample collection, we were limited to twice-weekly sampling. Knowing how quickly SARS-CoV-2 can spread and outbreaks can occur, a daily monitoring strategy would have much greater capacity to identify and mitigate secondary cases of COVID-19. Incident cases are likely to be clinically diagnosed in hospital far faster than in other high-risk facilities owing to greater resources and 
heightened suspicion - potentially leading to an even greater lead-time associated with a positive wastewater-signal of outbreaks than observed herein. Hospitals pose unique challenges in wastewater monitoring owing to these facilities' high use of chemical disinfectants and detergents[33] that could interfere with molecular assays; this may explain why $3.6 \%$ of our samples spiked controls and PMMoV were not detected by RT-qPCR. To minimize the risk of

304 false negatives, rigorous protocols that use internal controls (such as our BCoV spike) are necessary. The role of PCR-inhibitors in the wastewater matrix within the proximal sewershed is an area that deserves considerable study if this field is to expand.

Wastewater-based monitoring can only effectively monitor those individuals that contribute fecal matter to the sewershed. Importantly, hospitalized patients - those most vulnerable to COVID-19 adverse events - are often unable to self-toilet. Rather, these sick and often elderly individuals are dependent on continence aids, adult diapers, sanitary pads and nursing cleanup; this results in fecal matter from these individuals being disposed into biohazard solid waste. Accordingly, wastewater-

312 based sampling could miss between $10-20 \%$ of patients in general hospital patients[34, 35]. This

313 proportion is expected to be even higher in ICU where immobilization necessitated through

314 ventilatory support further heightens toileting assistance requirements. Adapting wastewater 315 surveillance technology to other high-risk settings like long-term care will encounter this same 316 limitation. Finally, - tracking workers through passive wastewater monitoring poses inherent 317 challenges. There is data that suggests that $52-56 \%$ of employees are uncomfortable defecating at 318 work $[36,37]$.

\section{Conclusion}


medRxiv preprint doi: https://doi.org/10.1101/2021.02.20.21251520; this version posted February 23, 2021. The copyright holder for this preprint (which was not certified by peer review) is the author/funder, who has granted medRxiv a license to display the preprint in perpetuity.

All rights reserved. No reuse allowed without permission.

320 In a five-month observational study we were able to detect SARS-CoV-2 from the wastewater of

321 Calgary's three largest tertiary-care hospitals. The rate of SARS-CoV-2 wastewater test-positivity

322 and RNA-abundance increased over time, concomitant with the increasing proportion of patients

323 hospitalized with COVID-19. Despite persistent low levels of SARS-CoV-2-RNA in wastewater

324 resulting from patients being treated for and recovering from COVID-19, we detected spikes

325 attributable to hospital-acquired infections and outbreaks. This study reveals that wastewater-

326 based monitoring of SARS-CoV-2 RNA holds promise for early detection, monitoring and

327 containment of incident infections. 
medRxiv preprint doi: https://doi.org/10.1101/2021.02.20.21251520; this version posted February 23, 2021. The copyright holder for this preprint

(which was not certified by peer review) is the author/funder, who has granted medRxiv a license to display the preprint in perpetuity.

All rights reserved. No reuse allowed without permission.

\section{FUNDING}

330 This work was supported by grants from the Canadian Institute of Health Research [448242 to

331 M.D.P.]; and Canadian Foundation for Innovation [41054 to C.R.J.H], as well as discretionary

332 start-up funding from the Cumming School of Medicine Infectious Disease Section-Chief Fund

333 (M.D.P.) and Campus Alberta Innovates Program Chair (C.R.J.H). 


\section{ACKNOWLEDGEMENTS}

336 The authors gratefully acknowledge the staff of the City of Calgary and in particular members of

337 Water Quality Services for their continued efforts for sample site planning, maintenance, and 338 collection. The authors are grateful to staff from Alberta Health Services and AHS Infection 339 Prevention and Control for assistance in data collection on patient disposition in the Calgary Zone. 340 The authors also thanks Cameron Semper for providing the pMCSG53 vector and T7/T7

341 terminator primers, and for providing support with Gibson assembly cloning. We would like to 342 acknowledge the tremendous efforts of Dr Rhonda Clark for program administration and 343 management.

344 All authors report no potential conflicts. All authors have submitted the ICMJE Form for 345 Disclosure of Potential Conflicts of Interest. 


\section{REFERENCES}

348 1. Foladori P, Cutrupi F, Segata N, et al. SARS-CoV-2 from faeces to wastewater treatment:

$349 \quad$ What do we know? A review. Sci Total Environ 2020; 743: 140444.

$350 \quad 2 . \quad$ Ling Y, Xu SB, Lin YX, et al. Persistence and clearance of viral RNA in 2019 novel coronavirus disease rehabilitation patients. Chin Med J (Engl) 2020; 133(9): 1039-43.

3. Gupta S, Parker J, Smits S, Underwood J, Dolwani S. Persistent viral shedding of SARSCoV-2 in faeces - a rapid review. Colorectal Dis 2020; 22(6): 611-20.

4. Medema G, Heijnen L, Elsinga G, Italiaander R, Brouwer A. Presence of SARSCoronavirus-2 RNA in Sewage and Correlation with Reported COVID-19 Prevalence in the Early Stage of the Epidemic in The Netherlands. Environ Sci Technol Lett 2020; 7: 511-6.

5. D'Aoust PM, Mercier E, Montpetit D, et al. Quantitative analysis of SARS-CoV-2 RNA from wastewater solids in communities with low COVID-19 incidence and prevalence.

6. Peccia J, Zulli A, Brackney DE, et al. Measurement of SARS-CoV-2 RNA in wastewater tracks community infection dynamics. Nat Biotechnol 2020; 38(10): 1164-7.

7. Ahmed W, Angel N, Edson J, et al. First confirmed detection of SARS-CoV-2 in

366 8. Wurtzer S, Marechal V, Mouchel J, et al. Evaluation of lockdown effect on SARS-CoV-2 
9. Ioannou GN, Locke E, Green P, et al. Risk Factors for Hospitalization, Mechanical Ventilation, or Death Among 10131 US Veterans With SARS-CoV-2 Infection. JAMA Netw Open 2020; 3(9): e2022310.

10. Carrillo-Vega MF, Salinas-Escudero G, Garcia-Pena C, Gutierrez-Robledo LM, ParraRodriguez L. Early estimation of the risk factors for hospitalization and mortality by COVID-19 in Mexico. PLoS One 2020; 15(9): e0238905.

11. Ko JY, Danielson ML, Town M, et al. Risk Factors for COVID-19-associated hospitalization: COVID-19-Associated Hospitalization Surveillance Network and Behavioral Risk Factor Surveillance System. Clin Infect Dis 2020.

12. Long DR, O'Reilly-Shah V, Rustagi AS, et al. Incidence of Health Care-Associated COVID-19 During Universal Testing of Medical and Surgical Admissions in a Large US Health System. Open Forum Infect Dis 2020; 7(10): ofaa435.

13. Carter B, Collins JT, Barlow-Pay F, et al. Nosocomial COVID-19 infection: examining the risk of mortality. The COPE-Nosocomial Study (COVID in Older PEople). J Hosp Infect 2020; 106(2): 376-84.

14. Hartnett KP, Kite-Powell A, DeVies J, et al. Impact of the COVID-19 Pandemic on Emergency Department Visits - United States, January 1, 2019-May 30, 2020. MMWR Morb Mortal Wkly Rep 2020; 69(23): 699-704.

15. Czeisler ME, Marynak K, Clarke KEN, et al. Delay or Avoidance of Medical Care Because of COVID-19-Related Concerns - United States, June 2020. MMWR Morb Mortal Wkly Rep 2020; 69(36): 1250-7. 
16. Whitney ON, Al-Shayeb B, Crits-Cristoph A, et al. V.4 -Direct wastewater RNA capture and purification via the "Sewage, Salt, Silica and SARS-CoV-2 (4S). Available at: https://dx.doi.org/10.17504/protocols.io.bpdfmi3n. Accessed 1 June 2020.

17. Randazzo W, Truchado P, Cuevas-Ferrando E, Simón P, Allende A, Sánchez G. SARSCoV-2 RNA in wastewater anticipated COVID-19 occurrence in a low prevalence area. Water research 2020; 181: 115942.

18. Wu F, Zhang J, Xiao A, et al. SARS-CoV-2 Titers in Wastewater Are Higher than Expected from Clinically Confirmed Cases. mSystems 2020; 5(4): e00614-20.

19. Harada S, Uno S, Ando T, et al. Control of a Nosocomial Outbreak of COVID-19 in a University Hospital. Open Forum Infect Dis 2020; 7(12): ofaa512.

20. Wang X, Zhou Q, He Y, et al. Nosocomial outbreak of COVID-19 pneumonia in Wuhan, China. Eur Respir J 2020; 55(6).

21. Backer JA, Klinkenberg D, Wallinga J. Incubation period of 2019 novel coronavirus (2019-nCoV) infections among travellers from Wuhan, China, 20-28 January 2020. Euro Surveill 2020; 25(5).

22. Arons MM, Hatfield KM, Reddy SC, et al. Presymptomatic SARS-CoV-2 Infections and Transmission in a Skilled Nursing Facility. N Engl J Med 2020; 382(22): 2081-90.

23. Yanes-Lane M, Winters N, Fregonese F, et al. Proportion of asymptomatic infection among COVID-19 positive persons and their transmission potential: A systematic review and meta-analysis. PLoS One 2020; 15(11): e0241536.

24. Johansson MA, Quandelacy TM, Kada S, et al. SARS-CoV-2 Transmission From People Without COVID-19 Symptoms. JAMA Netw Open 2021; 4(1): e2035057. 
412 25. Gonçalves J, Koritnik T, Mioč V, et al. Detection of SARS-CoV-2 RNA in hospital wastewater from a low COVID-19 disease prevalence area. Science of The Total Environment 2021; 755: 143226.

415

416

417

418

26. Ahmed W, Bertsch PM, Angel N, et al. Detection of SARS-CoV-2 RNA in commercial passenger aircraft and cruise ship wastewater: a surveillance tool for assessing the presence of COVID-19 infected travellers. J Travel Med 2020; 27(5).

27. Alygizakis N, Markou AN, Rousis NI, et al. Analytical methodologies for the detection of SARS-CoV-2 in wastewater: Protocols and future perspectives. Trends Analyt Chem 2021; 134: 116125.

28. Gonzalez R, Curtis K, Bivins A, et al. COVID-19 surveillance in Southeastern Virginia using wastewater-based epidemiology. Water Res 2020; 186: 116296.

29. Falzone L, Musso N, Gattuso G, et al. Sensitivity assessment of droplet digital PCR for SARS-CoV-2 detection. Int J Mol Med 2020; 46(3): 957-64.

30. Cheung KS, Hung IFN, Chan PPY, et al. Gastrointestinal Manifestations of SARS-CoV2 Infection and Virus Load in Fecal Samples From a Hong Kong Cohort: Systematic Review and Meta-analysis. Gastroenterology 2020; 159(1): 81-95.

31. Kitajima M, Sassi HP, Torrey JR. Pepper mild mottle virus as a water quality indicator. npj Clean Water 2018; 1(1): 19.

32. Colson P, Richet H, Desnues C, et al. Pepper mild mottle virus, a plant virus associated with specific immune responses, Fever, abdominal pains, and pruritus in humans. PLoS One 2010; 5(4): e10041.

33. Zotesso JP, Cossich ES, Janeiro V, Tavares CRG. Treatment of hospital laundry wastewater by UV/H2O2 process. Environ Sci Pollut Res Int 2017; 24(7): 6278-87. 
medRxiv preprint doi: https://doi.org/10.1101/2021.02.20.21251520; this version posted February 23, 2021. The copyright holder for this preprint

(which was not certified by peer review) is the author/funder, who has granted medRxiv a license to display the preprint in perpetuity.

All rights reserved. No reuse allowed without permission.

435 34. Condon M, Mannion E, Molloy DW, O'Caoimh R. Urinary and Faecal Incontinence: 2019; 16(2): 194.

438 35. Toba $\mathrm{K}$, Ouchi $\mathrm{Y}$, Orimo H, et al. Urinary incontinence in elderly inpatients in Japan: a comparison between general and geriatric hospitals. Aging (Milano) 1996; 8(1): 47-54.

440 36. Bennet J, McCall A. Women Poop. Sometime at work. Get over it. Available at: https://www.nytimes.com/2019/09/17/style/women-poop-at-work.html. Accessed 1 December 2020.

443 37. MacKenzie M. This is how many people refuse to poop at work-Are you one of them? Womens Health. Available at: 
448 Table 1. Descriptive statistics of SARS-CoV-2 RNA monitoring among wastewater hospital samples.

\begin{tabular}{|c|c|c|c|c|c|c|c|c|c|c|c|}
\hline \multirow[b]{2}{*}{ Hospital } & \multirow[b]{2}{*}{$\begin{array}{c}\text { Collection } \\
\text { period }\end{array}$} & \multirow[b]{2}{*}{$\begin{array}{c}\text { No. of } \\
\text { tested } \\
\text { samples }\end{array}$} & \multicolumn{3}{|c|}{ N1 } & \multicolumn{3}{|c|}{$\mathbf{N 2}$} & \multicolumn{3}{|c|}{$\mathbf{E}^{\beta}$} \\
\hline & & & $\begin{array}{c}\text { \% of } \\
(+) \\
\text { SARS- } \\
\text { CoV-2* }\end{array}$ & $\begin{array}{c}\mathrm{Cq} \\
\text { median } \\
(\mathrm{IQR})\end{array}$ & $\begin{array}{c}\text { Cq } \\
\text { range }^{\dagger}\end{array}$ & $\begin{array}{c}\text { \% of } \\
(+) \\
\text { SARS- } \\
\text { CoV-2* }\end{array}$ & $\begin{array}{c}\mathrm{Cq} \\
\text { median } \\
(\mathrm{IQR})\end{array}$ & $\begin{array}{c}\text { Cq } \\
\text { range }^{\dagger}\end{array}$ & $\begin{array}{c}\% \text { of }(+) \\
\text { SARS- } \\
\text { CoV-2* }\end{array}$ & $\begin{array}{c}\mathrm{Cq} \\
\text { median } \\
(\mathrm{IQR})\end{array}$ & $\begin{array}{c}\mathbf{C q} \\
\text { range }^{\dagger}\end{array}$ \\
\hline 1 & $\begin{array}{c}\text { August } 5^{\text {th }} \\
\text { to } \\
\text { December } \\
17^{\text {th }}\end{array}$ & 40 & 62.5 & $\begin{array}{c}32.5 \\
(30.6- \\
36.4)\end{array}$ & 12.5 & 50 & $\begin{array}{c}35.3 \\
(33.5- \\
37.7)\end{array}$ & 13.5 & 7.5 & $\begin{array}{c}35.5 \\
(31.3- \\
37.3)\end{array}$ & 12.1 \\
\hline 2 & $\begin{array}{c}\text { August } 5^{\text {th }} \\
\text { to } \\
\text { December } \\
17^{\text {th }}\end{array}$ & 40 & 45 & $\begin{array}{c}31.8- \\
35.9\end{array}$ & 8.6 & 35 & $\begin{array}{c}35.9 \\
(34.5- \\
37.8)\end{array}$ & 9.04 & 0 & - & - \\
\hline $3 \mathrm{~A}$ & $\begin{array}{c}\text { August } 5^{\text {th }} \\
\text { to } \\
\text { December } \\
17^{\text {th }}\end{array}$ & 39 & 51.3 & $\begin{array}{c}32.8 \\
(30.7- \\
35.6)\end{array}$ & 11.9 & 48.7 & $\begin{array}{c}36.2 \\
(33.2- \\
41.2)\end{array}$ & 16.3 & 12.8 & $\begin{array}{c}30.6 \\
(28.5- \\
30.7)\end{array}$ & 5.7 \\
\hline $3 B$ & $\begin{array}{c}\text { October } 1^{\text {st }} \\
\text { to } \\
\text { December } \\
17^{\text {th }}\end{array}$ & 23 & 91.3 & $\begin{array}{c}34.6 \\
(33.8- \\
36.5)\end{array}$ & 8.3 & 73.9 & $\begin{array}{c}39.6 \\
(38.1- \\
41.7)\end{array}$ & 9.7 & 0 & - & - \\
\hline
\end{tabular}




\begin{tabular}{|c|c|c|c|c|c|c|c|c|c|c|c|}
\hline & October $1^{\text {st }}$ & & & & & & & & & & \\
\hline $3 C$ & $\begin{array}{c}\text { to } \\
\text { December } \\
17^{\text {th }}\end{array}$ & 23 & 78.3 & $\begin{array}{c}36.4 \\
(34.7- \\
37.1)\end{array}$ & 11.07 & 52.2 & $\begin{array}{c}41.1 \\
(39.7- \\
41.7)\end{array}$ & 13.08 & 4.3 & 34.9 & - \\
\hline
\end{tabular}

449

* Percentage of samples positive for SARS-CoV2 (no. of positive samples/no. of tested samples).

$450 \dagger$ Range is the difference between the max and min value for $\mathrm{Cq}$, cycle of quantification.

$451{ }^{\beta}$ E assay was performed for samples collected from August $5^{\text {th }}$ to October $29^{\text {th }}$. 
Table 2. Correlation analyses between SARS-CoV-2 RNA signal in wastewater from Calgary Hospitals with daily-prevalent cases of

454 patients hospitalized with COVID-19 and those incident hospital-acquired cases.

455

\begin{tabular}{|c|c|c|c|c|c|c|c|c|c|c|}
\hline \multirow{2}{*}{ Hospital } & \multirow{2}{*}{ Comparison } & \multicolumn{3}{|c|}{$\mathbf{C q}$} & \multicolumn{3}{|c|}{ Copies/ml } & \multicolumn{3}{|c|}{ Copies/Copies PMMoV ${ }^{\dagger}$} \\
\hline & & $\mathbf{r}$ & P-value & $95 \% \mathrm{CI}$ & $\mathbf{r}$ & P-value & $95 \% \mathrm{CI}$ & $\mathbf{r}$ & P-value & $95 \% \mathrm{CI}$ \\
\hline \multirow{3}{*}{1} & N1 vs N2 & 0.710 & $<0.0001$ & $\begin{array}{c}0.511- \\
0.836\end{array}$ & - & - & - & - & - & - \\
\hline & $\mathrm{N} 1$ vs prevalent & 0.486 & 0.0027 & $\begin{array}{c}0.187- \\
0.702\end{array}$ & 0.290 & 0.0858 & $\begin{array}{c}-0.0422- \\
0.565\end{array}$ & 0.187 & 0.2737 & $\begin{array}{c}-0.150- \\
0.486\end{array}$ \\
\hline & N1 vs incident* & 0.537 & 0.0005 & $\begin{array}{c}0.263- \\
0.731\end{array}$ & 0.279 & 0.0896 & $\begin{array}{c}-0.0445- \\
0.550\end{array}$ & 0.277 & 0.0920 & $\begin{array}{c}-0.0466- \\
0.548\end{array}$ \\
\hline \multirow{3}{*}{2} & N1 vs N2 & 0.762 & $<0.0001$ & $\begin{array}{c}0.587- \\
0.868\end{array}$ & - & - & - & - & - & - \\
\hline & $\mathrm{N} 1$ vs prevalent & 0.862 & $<0.0001$ & $\begin{array}{c}0.742- \\
0.929\end{array}$ & 0.542 & 0.0008 & $\begin{array}{c}0.255- \\
0.741\end{array}$ & 0.534 & 0.0009 & $\begin{array}{c}0.245- \\
0.736\end{array}$ \\
\hline & N1 vs incident* & 0.474 & 0.0030 & $\begin{array}{c}0.177- \\
0.692\end{array}$ & $\begin{array}{c}0.25 \\
5\end{array}$ & 0.1273 & $\begin{array}{c}-0.0750- \\
0.535\end{array}$ & 0.283 & 0.0900 & $\begin{array}{c}-0.0455- \\
0.556\end{array}$ \\
\hline $3 \mathrm{~A}$ & $\mathrm{~N} 1$ vs N2 & 0.792 & $<0.0001$ & $\begin{array}{c}0.620- \\
0.892\end{array}$ & - & - & - & - & - & - \\
\hline
\end{tabular}




\begin{tabular}{|c|c|c|c|c|c|c|c|c|c|c|}
\hline & $\begin{array}{c}\mathrm{N} 1 \mathrm{vs} \\
\text { prevalent } \#\end{array}$ & 0.717 & $<0.0001$ & $\begin{array}{c}0.481- \\
0.856\end{array}$ & $\begin{array}{c}0.20 \\
2\end{array}$ & 0.2840 & $\begin{array}{c}-0.171- \\
0.524\end{array}$ & 0.147 & 0.4382 & $\begin{array}{c}-0.225- \\
0.482\end{array}$ \\
\hline & N1 vs incident* & 0.350 & 0.0492 & $\begin{array}{c}0.00201- \\
0.623\end{array}$ & $\begin{array}{c}0.46 \\
3\end{array}$ & 0.0077 & $\begin{array}{c}0.136- \\
0.699\end{array}$ & 0.444 & 0.0109 & $\begin{array}{c}0.113- \\
0.686\end{array}$ \\
\hline \multirow{3}{*}{$3 \mathrm{~B}$} & $\mathrm{~N} 1$ vs N2 & 0.417 & 0.0478 & $\begin{array}{c}0.00565- \\
0.708\end{array}$ & - & - & - & - & - & - \\
\hline & $\begin{array}{c}\text { N1 vs } \\
\text { prevalent\# }\end{array}$ & 0.139 & 0.5709 & $\begin{array}{c}-0.337- \\
0.558\end{array}$ & $\begin{array}{c}0.13 \\
5\end{array}$ & 0.5821 & $\begin{array}{c}-0.340- \\
0.555\end{array}$ & $\begin{array}{c}- \\
0.139\end{array}$ & 0.5707 & $\begin{array}{c}-0.558- \\
0.337\end{array}$ \\
\hline & N1 vs incident* & 0.0654 & 0.7783 & $\begin{array}{c}-0.377- \\
0.483\end{array}$ & $\begin{array}{c}- \\
0.03 \\
96\end{array}$ & 0.8645 & $\begin{array}{c}-0.463- \\
0.399\end{array}$ & 0.187 & 0.4179 & $\begin{array}{c}-0.267- \\
0.572\end{array}$ \\
\hline \multirow{3}{*}{$3 \mathrm{C}$} & N1 vs N2 & 0.491 & 0.0174 & $\begin{array}{c}0.0987- \\
0.751\end{array}$ & - & - & - & - & - & - \\
\hline & $\begin{array}{c}\text { N1 vs } \\
\text { prevalent } \#\end{array}$ & $\begin{array}{c}- \\
0.0929\end{array}$ & 0.7052 & $\begin{array}{c}-0.525- \\
0.377\end{array}$ & $\begin{array}{c}0.50 \\
3\end{array}$ & 0.0282 & $\begin{array}{c}0.0632- \\
0.779\end{array}$ & 0.479 & 0.0379 & $\begin{array}{c}0.0318- \\
0.767\end{array}$ \\
\hline & N1 vs incident* & 0.266 & 0.2433 & $\begin{array}{c}-0.187- \\
0.626\end{array}$ & $\begin{array}{c}- \\
0.04 \\
81\end{array}$ & 0.8361 & $\begin{array}{c}-0.470- \\
0.392\end{array}$ & $\begin{array}{c}0.006 \\
04\end{array}$ & 0.9793 & $\begin{array}{c}-0.427- \\
0.437\end{array}$ \\
\hline
\end{tabular}

* Average of incident hospital acquired cases (-/+3 days from sample collection).

$457 \dagger$ Relative SARS-CoV2 genomic copies compared to genomic copies of PMMoV.

458 \# Prevalent cases at Hospital-3 are reported for the entire facility - as opposed to those cases directly housed in 3A, 3B, 3C. 
459 Cq, quantification cycle. 
medRxiv preprint doi: https://doi.org/10.1101/2021.02.20.21251520; this version posted February 23, 2021. The copyright holder for this preprint (which was not certified by peer review) is the author/funder, who has granted medRxiv a license to display the preprint in perpetuity.

All rights reserved. No reuse allowed without permission.

460

Table 3. SARS-CoV-2 RNA detection in hospital-wastewater samples as a function of proximity

461 to a declared outbreak.

\section{Outbreak-free periods vs}

Hospital Measurement outbreaks

P-value

(Median (IQR))

\begin{tabular}{|c|c|c|c|}
\hline \multirow{2}{*}{1} & Copies/ml & $0(0-7.9)$ vs $280(35-1768)$ & $<0.0001$ \\
\hline & Copies/Copies PMMoV & $0(0-0.07)$ vs $0.18(0.09-1.8)$ & 0.0001 \\
\hline \multirow{2}{*}{2} & Copies/ml & $0(0-0)$ vs $8(1.1-17)$ & 0.022 \\
\hline & Copies/Copies PMMoV & $0(0-0)$ vs $0.035(0-0.21)$ & 0.453 \\
\hline \multirow{2}{*}{$3 \mathrm{~A}$} & Copies/ml & $0(0-12)$ vs $122(5.9-408)$ & 0.031 \\
\hline & Copies/Copies PMMoV & $0(0-0.11)$ vs $0.5(0.01-10)$ & 0.026 \\
\hline \multirow{2}{*}{$3 \mathrm{C}$} & Copies/ml & $2.4(0-8.8)$ vs $26(1.1-3179)$ & 0.212 \\
\hline & Copies/Copies PMMoV & $0.013(0-0.08)$ vs $0.1(0.0003-6.9)$ & 0.253 \\
\hline
\end{tabular}

462

463 


\section{FIGURES LEGENDS}

465

466

467

468

469

470

471

472

473

474

475

476

477

\section{Figure 1. Determination of SARS-CoV-2 RNA in wastewater samples from Hospital-1 and}

Hospital-2. Relative SARS-CoV-2 genomic copies compared to genomic copies of PMMoV from A) Hospital 1 (August $5^{\text {th }}$ to December $17^{\text {th }}$ ) and B) Hospital 2 (August $5^{\text {th }}$ to December $17^{\text {th }}$ ). Quantification of SARS-CoV-2 RNA in samples was determined by the N1 (black) and N2 (red) assays. Green line denotes the total daily number of active prevalent cases in the hospital. Orange bars denotes the number of daily hospital-acquired cases. Plots show the average of three technical replicates and error bars represent the standard deviation. Vertical dash lines correspond to days where outbreaks were declared (Table S3), where the number of patients and health care workers involved are indicated at the top each dotted dash line. Asterisk denotes that for a specific outbreak more than one unit was involved. Gray zones denote duration of the outbreak. HA: hospital acquired. Bottom individual boxed areas represent individual samples as Positives $(+)=$ samples where SARS-CoV-2 signal identified with a $\mathrm{Cq}<40$, and negatives (-) had values $\geq 40$. Please note that the scale is different in Figure A and B.

\section{Figure 2. Determination of SARS-CoV-2 RNA in wastewater samples from Hospital-3.}

Relative SARS-CoV-2 genomic copies compared to genomic copies of PMMoV from A) Hospital 3A (Trauma, Medical \& Surgical ICUs, orthopedics surgery and designated COVID-care units) August $5^{\text {th }}$ to December $17^{\text {th }}$ ), B) Hospital 3B (i.e., Main Building, North wing, October $1^{\text {st }}$ to December $17^{\text {th }}$ ) and C) Hospital3C (i.e., Main Building South Wing, cancer care building, complex medical care building and hostel/administration building), October $1^{\text {st }}$ to December $17^{\text {th }}$ ). Quantification of SARS-CoV-2 RNA in samples was determined by the N1 (black) and N2 (red) assays. Green line denotes the number of prevalent cases in the hospital. Orange bars denotes the number of daily hospital-acquired cases. Plots show the average of three technical replicates and 
487 error bars represent the standard deviation. Vertical dash lines correspond to days where outbreaks 488 were declared (Table S3), where the number of patients and health care workers involved are 489 indicated at the top each dotted dash line. Asterisk $\left(^{*}\right)$ denotes the largest outbreak which occurred 490 initially at Hospital_3C prior to instituted monitoring at that site - and reflects the SARS-CoV-2

491 infected patients who were relocated to the designated COVID-19 wards inHospital_3A where it 492 was detected by wastewater monitoring. The last case associated with the large outbreak was 493 identified October $19^{\text {th }}$. Gray zones denote duration of the outbreak. HA: hospital acquired. Bottom 494 individual boxed areas represent individual samples as Positives $(+)=$ samples where SARS-CoV4952 signal identified with a $\mathrm{Cq}<40$, and negatives (-) had values $\geq 40$. Please note that the scale is 496 different from A, B and C figures. 
medRxiv preprint doi: https://doi.org/10.1101/2021.02.20.21251520; this version posted February 23, 2021. The copyright holder for this preprint (which was not certified by peer review) is the author/funder, who has granted medRxiv a license to display the preprint in perpetuity. All rights reserved. No reuse allowed without permission.

\section{FIGURES}

\section{Figure 1}

A

Outbreaks:

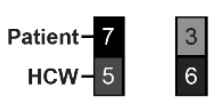

*
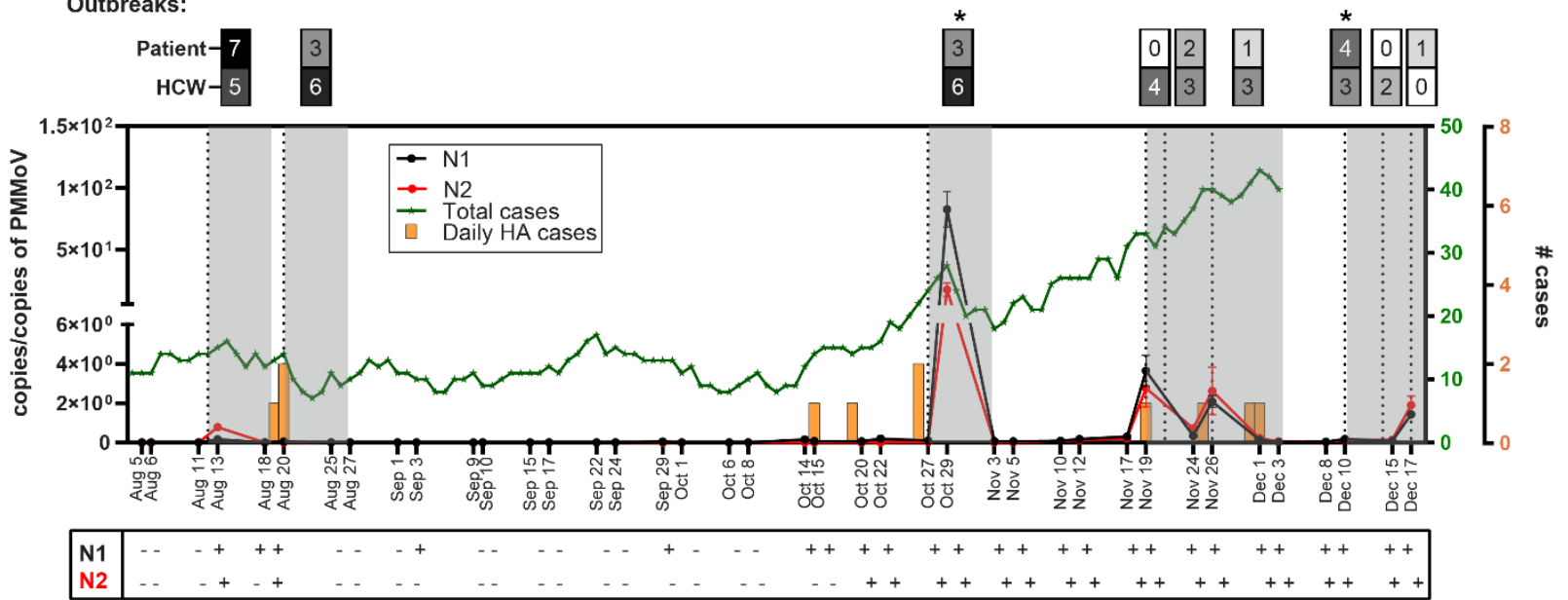

B

Outbreaks:
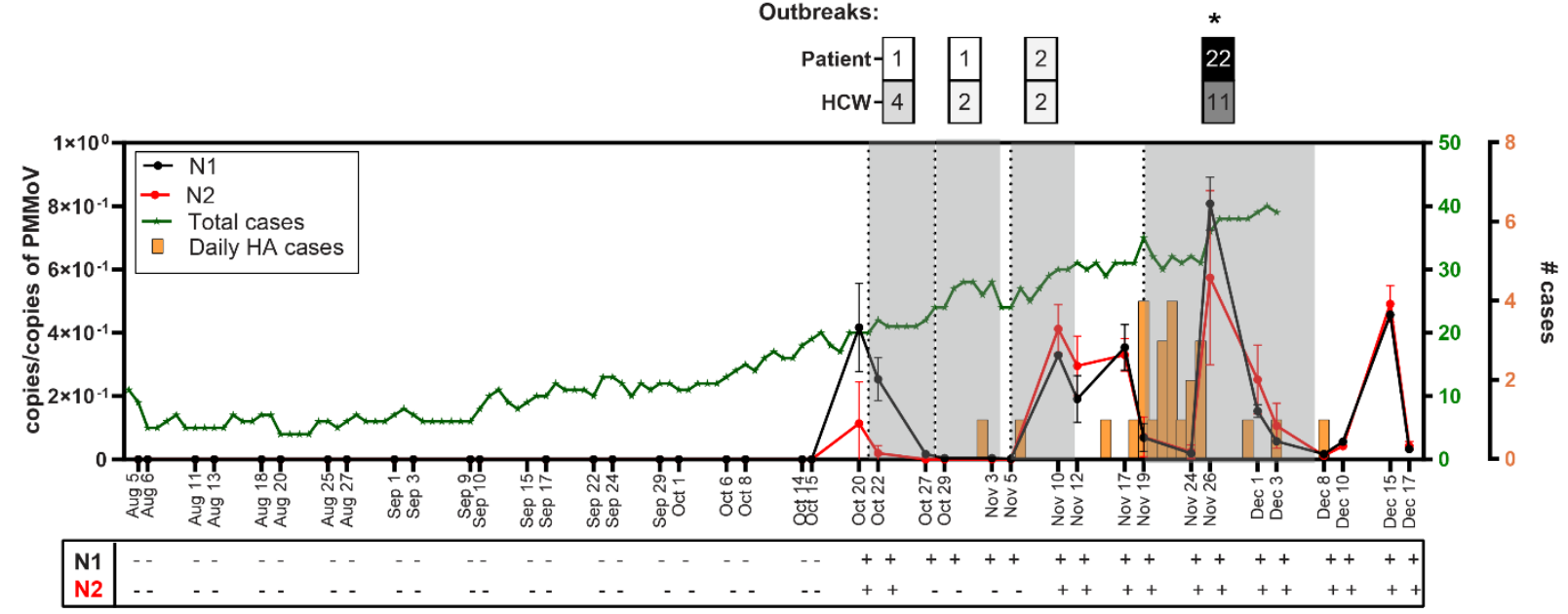
medRxiv preprint doi: https://doi.org/10.1101/2021.02.20.21251520; this version posted February 23, 2021. The copyright holder for this preprint (which was not certified by peer review) is the author/funder, who has granted medRxiv a license to display the preprint in perpetuity.

Figure 2

A Outbreak (Site 3C):

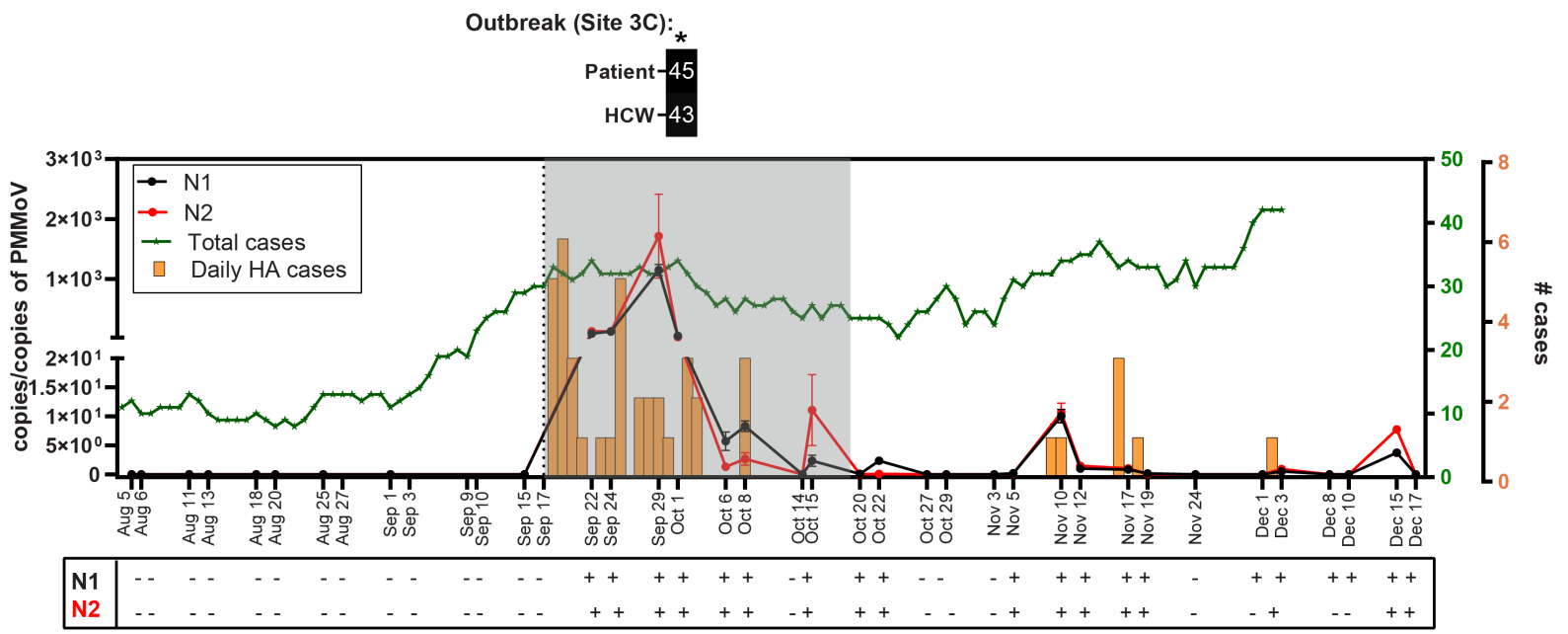

B

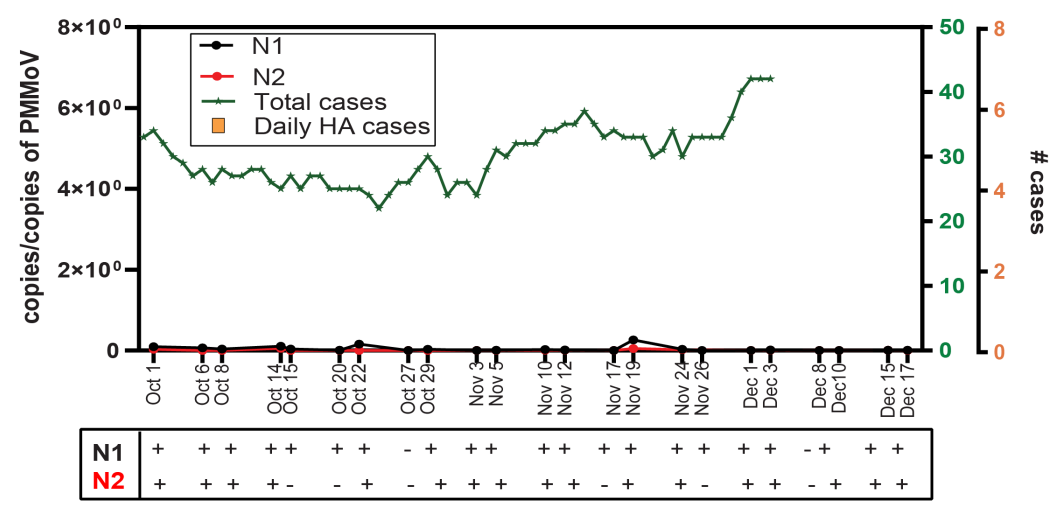

C

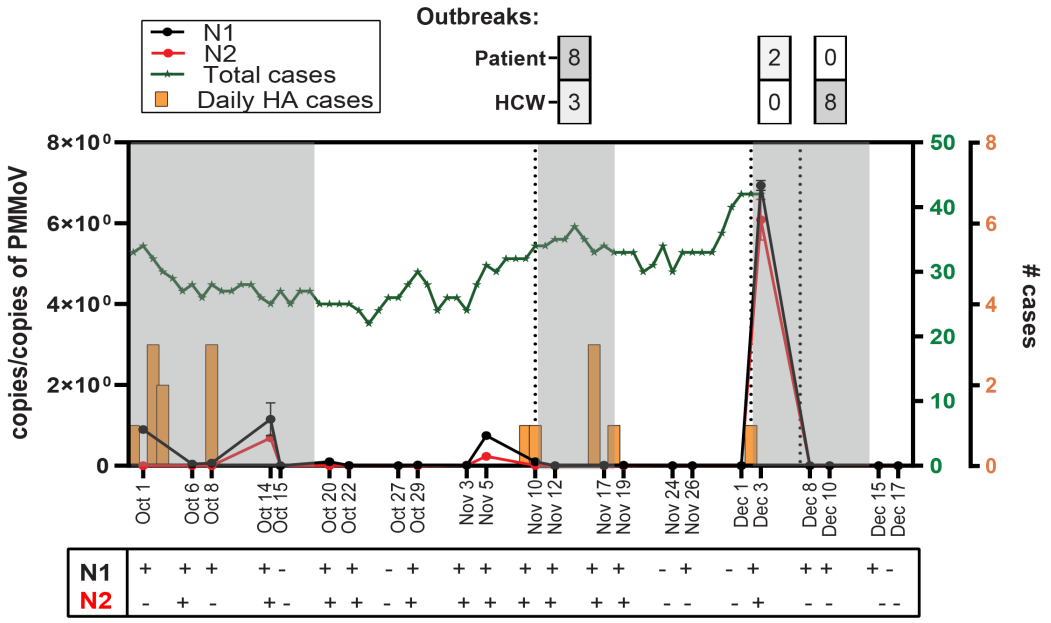

